\title{
Assessment of RET/PTC1 and RET/PTC3 rearrangements in fine-needle aspiration biopsy specimens collected from patients with Hashimoto's thyroiditis
}

Anna Cyniak-Magierska 1,2, Katarzyna Wojciechowska-Durczyńska ${ }^{1,2}$, Kinga Krawczyk-Rusiecka 1,2, Arkadiusz Zygmunt ${ }^{1,2}$, Andrzej Lewiński ${ }^{1,2^{*}}$

\begin{abstract}
Background: RET/PTC rearrangements are the most frequent molecular changes in papillary thyroid carcinoma (PTC). So far, 15 main RET/PTC rearrangements have been described, among which RET/PTC1 and RET/PTC3 are the most common in PTC - especially in radiation-induced tumours. RET/PTC1 and RET/PTC3 are the result of intrachromosomal paracentric inversions in chromosome 10, where RET and the activating genes (H4 and ELE1, respectively) are located. Recently, RET/PTC rearrangements have been shown not only in PTC but also in benign thyroid lesions, including Hashimoto's thyroiditis (HT). The aim of study was an assessment of RET/PTC1 and RET/ PTC3 rearrangements in patients with Hashimoto's thyroiditis.
\end{abstract}

Materials and methods: Thyroid aspirates, eligible for the study, were obtained from 26 patients with Hashimoto's thyroiditis by fine-needle aspiration biopsy (FNAB). Each aspirate was smeared for conventional cytology, while its remaining part was immediately washed out of the needle. The cells, obtained from the needle, were used in further investigation. Total RNA from FNAB was extracted by use of an RNeasy Micro Kit, based on modified Chomczynski and Sacchi's method and reverse transcription (RT-PCR) was done. Quantitative evaluation of RET/ PTC1 and RET/PTC3 rearrangements by real-time PCR was performed by an ABI PRISM ${ }^{\circledR} 7500$ Sequence Detection System. In the study, PTC tissues with known RET/PTC1 and RET/PTC3 rearrangements served as a reference standard (calibrator), while $\beta$-actin gene was used as endogenous control.

Results: Amplification reactions were done in triplicate for each examined sample. No RET/PTC1 and RET/PTC3 rearrangements were found in the examined samples.

Conclusions: Our results indicate that RET/PTC1 and RET/PTC3 rearrangements in Hashimoto's thyroiditis, if any, are rather rare events and further investigations should be conducted in order to determine molecular changes, connecting Hashimoto's thyroiditis with PTC.

\section{Background}

Chromosomal rearrangements involving $R E T$ receptor tyrosine kinase (TK) protooncogene $(R E T / P T C)$ are a specific feature of papillary thyroid carcinoma (PTC). The RET protooncogene is activated by fusion of 3'-terminal portion of $R E T$, coding for TK domain, with

\footnotetext{
*Correspondence: alewin@csk.umed.lodz.pl

'Department of Endocrinology and Metabolic Diseases, Medical University of Lodz, Poland

Full list of author information is available at the end of the article
}

the 5 ' terminal region of different unrelated genes, leading to constitutive activation of the RET TK [1]. There are - at least -15 different RET/PTC rearrangements [2], but the two: RET/PTC1 and RET/PTC3 are the most common ones [3]. RET/PTC1 is formed by fusion with the $H 4$ gene [1], and RET/PTC3 by fusion with the ELE1 (also designed NCOA4, RFG or ARA70) gene [4]. However, apart from RET/PTC1 and RET/PTC3, all the other variants of rearrangements do not seem to have

\section{() Biomed Central}


an important role in the pathogenesis of PTC since they have been isolated just in rare cases [5].

Chromosomal rearrangements of RET in PTC were found with different frequency, depending on geographic variability and studied population. The reported frequency of RET/PTC in PTC varies from 0 to $87 \%$ [6]. It is interesting that the frequency of $R E T / P T C$ rearrangements not only depends on geographical region but also on applied technique of identification [6].

The relatively high prevalence of $R E T / P T C$ rearrangements was described in tumours associated with radiation exposure [7]. The higher prevalence of RET/PTC3 activation in PTC was observed in the contaminated areas after Chernobyl explosion [7]. The analysis of PTC, which developed after a long latency period after explosion showed higher prevalence of $R E T / P T C 1$ rearrangements [8]. This can suggest that $R E T / P T C 3$ rearrangements may be typical for radiation-induced childhood PTC with a short latency period, while RET/PTC1 rearrangements may be a marker for later-occurring PTC of radiationexposed children and adults [8]. RET/PTC rearrangements have not been found in follicular thyroid carcinomas and anaplastic thyroid carcinomas [9].

Recently, RET/PTC rearrangements have been shown not only in PTC but also in Hürthle thyroid adenomas and carcinomas and also in Hashimoto's thyroiditis (HT) $[10,11]$.

The prevalence of RET/PTC rearrangements in HT is still controversial. The study aimed at estimating the frequency of rearrangements of RET protooncogene in HT in the Polish population.

\section{Materials and methods}

The Ethical Committee of the Medical University of Lodz approved the studies in this paper.

\section{Patients}

Thyroid aspirates, eligible for this study, were obtained from patients undergoing FNAB for Hashimoto's thyroiditis. All tissue samples were taken after patients' informed consent was obtained. FNAB specimens from 26 patients ( 25 women, 1 man) were examined. Data characterising the patients involved in the study are presented in Table 1. The mean age of patients was $52.8 \pm$ 15.4 years (mean $\pm \mathrm{SD}$ ), ranging from 18 to 88 years.

Thyroiditis was diagnosed, according to clinical symptoms and signs, together with data of hormonal and immunological tests and the results of cytological evaluation of FNAB specimens, collected under ultrasound guidance.

Ultrasound-guided FNAB was performed with the use of a 22-gauge needle and each aspirate was smeared for conventional cytology, while the remaining material was immediately washed out of the needle with $350 \mu \mathrm{l}$ of
Table 1 Characteristics of HT patients involved in the study

\begin{tabular}{|c|c|c|c|}
\hline Case number & Sex & Age & Diagnosis \\
\hline 1 & $\mathrm{~F}$ & 68 & HT \\
\hline 2 & $\mathrm{~F}$ & 67 & HT \\
\hline 3 & $\mathrm{~F}$ & 48 & HT \\
\hline 4 & $F$ & 45 & HT \\
\hline 5 & $\mathrm{~F}$ & 37 & HT \\
\hline 6 & $F$ & 68 & HT \\
\hline 7 & $\mathrm{~F}$ & 18 & HT \\
\hline 8 & $\mathrm{~F}$ & 53 & HT \\
\hline 9 & $\mathrm{~F}$ & 31 & HT \\
\hline 10 & $F$ & 52 & HT \\
\hline 11 & $\mathrm{~F}$ & 63 & HT \\
\hline 12 & $F$ & 54 & HT \\
\hline 13 & $\mathrm{~F}$ & 83 & HT \\
\hline 14 & $\mathrm{~F}$ & 88 & HT \\
\hline 15 & $\mathrm{~F}$ & 39 & HT \\
\hline 16 & $F$ & 50 & HT \\
\hline 17 & $\mathrm{~F}$ & 51 & HT \\
\hline 18 & $\mathrm{~F}$ & 41 & HT \\
\hline 19 & $\mathrm{~F}$ & 41 & HT \\
\hline 20 & $\mathrm{~F}$ & 49 & HT \\
\hline 21 & $\mathrm{~F}$ & 38 & HT \\
\hline 22 & $F$ & 65 & HT \\
\hline 23 & $\mathrm{~F}$ & 51 & HT \\
\hline 24 & $\mathrm{~F}$ & 54 & HT \\
\hline 25 & $\mathrm{~F}$ & 63 & HT \\
\hline 26 & $M$ & 57 & HT \\
\hline
\end{tabular}

RLT lysis buffer, containing $\beta$-mercaptoethanol and guanidine thiocyanate, used for RNA isolation (Qiagen, Germany). The samples were immediately frozen at $-70^{\circ} \mathrm{C}$ and, thus, stored until total RNA isolation. The samples, containing visible blood contamination, were disqualified from further investigations.

\section{RNA extraction from FNAB}

Total RNA from FNAB was extracted with the use of RNeasy Micro Kit (Qiagen, Germany). The manufacturer's instructions were followed, except that the cell lysate was applied for the second time to the column before the wash-step was carried out. The quality and quantity of total RNA was spectrophotometrically measured and - for some samples - with an Agilent 2100 Bioanalyzer.

\section{Reverse transcription}

Reverse transcription (RT) was performed, using the whole RNA, extracted with TaqMan ${ }^{\circledR}$ Reverse Transcripton Reagents (Applied Biosystems, Branchburg, 
New Jersey, USA). RT reaction mixture contained $5 \mu \mathrm{l}$ of $10 \times$ TaqMan RT Buffer $(100 \mathrm{mM}$ Tris- $\mathrm{HCl}$ pH 8.3, $500 \mathrm{mM} \mathrm{KCl}$ ), $11.0 \mu \mathrm{l} 25 \mathrm{mM} \mathrm{MgCl}_{2}, 1.25 \mu \mathrm{l}$ Multi Scribe $^{\mathrm{TM}}$ reverse transcriptase $(50 \mathrm{U} / \mu \mathrm{l}), 2.5 \mu \mathrm{l} 50 \mu \mathrm{M}$ oligo $(\mathrm{dT})_{16}, 1.0 \mu \mathrm{l}$ RNase Inhibitor - RI $(20 \mathrm{U} / \mu \mathrm{l})$, and $10 \mu \mathrm{l} 10 \mathrm{mM}$ dNTPs in a total volume of $50 \mu \mathrm{l}$. RNAs were incubated for 10 minutes at $25^{\circ} \mathrm{C}$, followed by 30 minutes at $48^{\circ} \mathrm{C}$ and 5 minutes at $95^{\circ} \mathrm{C}$ to inactivate reverse transcriptase (Multi Scribe ${ }^{\mathrm{Tm}}$ ). Negative controls were performed simultaneously to eliminate a possible genomic DNA contamination (no reverse transcriptase reactions), as well as to eliminate a possible contamination of RT reagents (no RNA-added reactions).

\section{Real-time quantitative PCR}

An established Relative Quantification Polymerase Chain Reaction (RQ-PCR) assay for RET/PTC1 and RET/PTC3 mRNA expressions, using the relative quantification method $\left(\Delta \Delta C_{\mathrm{T}}\right)$ were conducted in ABI PRISM 7500 Sequence Detection System (Applied Biosystems), according to the manufacturer's protocol. The PCR reactions for RET/PTC1 and RET/PTC3 rearrangements of genes were run with $50 \mathrm{ng}$ of cDNA in a total volume of $50 \mu \mathrm{l}$, using TaqMan ${ }^{\circledR}$ Universal PCR Master Mix (Applied Biosystems, Foster City, CA, USA) and the predesigned and labelled primer/probe set (Applied Biosystems, Foster City, CA, USA). Sequences of primers and probes used for this study were reported and validated according to Rhoden's et al. protocol (Table 2) [12]. After initial incubation at $50^{\circ} \mathrm{C}$ for $2 \mathrm{~min}$ to allow uracil-N-glycosylase (UNG) digestion, and at $95^{\circ} \mathrm{C}$ for 10 min to activate the AmpliTaq Gold ${ }^{\circledR}$ DNA polymerase, both of them were provided by the Universal PCR Master Mix, the samples were amplified through 45 biphasic cycles of $95^{\circ} \mathrm{C}$ for $15 \mathrm{sec}$ and $60^{\circ} \mathrm{C}$ for $1 \mathrm{~min}$ (Table 3).

In the study, PTC tissues with known RET/PTC1 and RET/PTC3 rearrangements served as a reference standard (calibrator) [13]. Amplification reactions were done in triplicate for each sample (cDNA from the same PCR reaction but in separate wells). Controls with no template cDNA were used with each assay (negative control).

The expression levels of $\beta$-actin gene $(A C T B)$ were measured, as endogenous control (reference gene), using the appropriate Assays-on-Demand ${ }^{\mathrm{TM}}$ Gene Expression product (Hs99999903_ml, Applied Biosystems Foster City, CA, USA).
Table 3 Amplification conditions for RET/PTC1 and RET/ PTC3 rearrangements using real-time PCR

\begin{tabular}{|c|c|c|c|}
\hline \multicolumn{4}{|c|}{ Times and temperatures } \\
\hline \multirow{2}{*}{\multicolumn{2}{|c|}{ Initial setup }} & \multicolumn{2}{|c|}{ Each of 45 cycles } \\
\hline & & Denaturation & $\begin{array}{l}\text { Annealing/ } \\
\text { Elongation }\end{array}$ \\
\hline HOLD & HOLD & \multicolumn{2}{|c|}{ CYCLE } \\
\hline $\begin{array}{l}\text { UNG activation } 2 \mathrm{~min} \text {, } \\
50^{\circ} \mathrm{C}\end{array}$ & $\begin{array}{l}10 \mathrm{~min} \\
95^{\circ} \mathrm{C}\end{array}$ & $15 \mathrm{~s}, 95^{\circ} \mathrm{C}$ & $1 \mathrm{~min}, 60^{\circ} \mathrm{C}$ \\
\hline
\end{tabular}

Both gene expressions were measured for each thyroid lesion sample in the same PCR reaction but in separate wells.

Results were presented as $\mathrm{Rn}$ (normalized receptor) versus cycle graph, where $\mathrm{Rn}$ is the fluorescence of the receptor dye, divided by fluorescence of a passive reference dye (Figure 1 and 2).

\section{Results}

The specimens were amplified in the ABI PRISM 7500 Sequence Detection System in reaction, containing primers and probes for RET/PTC1 and RET/PTC3 rearrangements and a control gene, $\beta$-actin. The Sequence Detection System software, provided with the instrument, analyses the fluorescence data, generated during the reaction, and calculates the cycle number at which fluorescence crosses the threshold value $\left(\mathrm{C}_{\mathrm{T}}\right)$. Amplification reactions were done in triplicate for each examined sample.

No RET/PTC1 and RET/PTC3 rearrangements were found in the examined HT specimens (for RET/PTC1 see Figure 1 and 2; for RET/PTC3 - data not shown).

\section{Discussion}

The prevalence of RET/PTC rearrangements in Hashimoto's thyroiditis remains a subject of controversy. Some authors have described activation of RET protooncogene in the majority number of HT patients. Sheils et al. [14] have shown the presence of RET/PTC1 rearrangement in a significant number of HT cases (95\%). The majority of specimens have shown no evidence of concomitant PTC [14]. Wirtschafter et al. also have documented the presence of transcripts of RET/PTC1 and RET/PTC3 in $95 \%$ cases of HT [15]. Their study has suggested that multiple, independent occult PTCs exist in patients with $\mathrm{HT}$ at high frequency and RET/ PTC1 and RET/PTC3 are early molecular markers of

Table 2 The sequences of probes and primers of RET/PTC1 and RET/PTC3 gene rearrangements [12]

\begin{tabular}{ccccc}
\hline Gene & Amplicon $(\mathbf{b p})$ & Forward primer & Reverse primer & Probe sequence \\
\hline RET/PTC1 & 66 & CGCGACCTGCGCAAA & CAAGTTCTTCCGAGGGAATTCC & 6FAM-CAAGCGTAACCATCGAGGATCCAAAGT-TAMRA \\
\hline RET/PTC3 & 81 & CCCCAGGACTGGCTTACCC & CAAGTTCTTCCGAGGGAATTCC & 6FAM-AAAGCAGACCTTGGAGAACAGTCAGGAGG-TAMRA \\
\hline
\end{tabular}




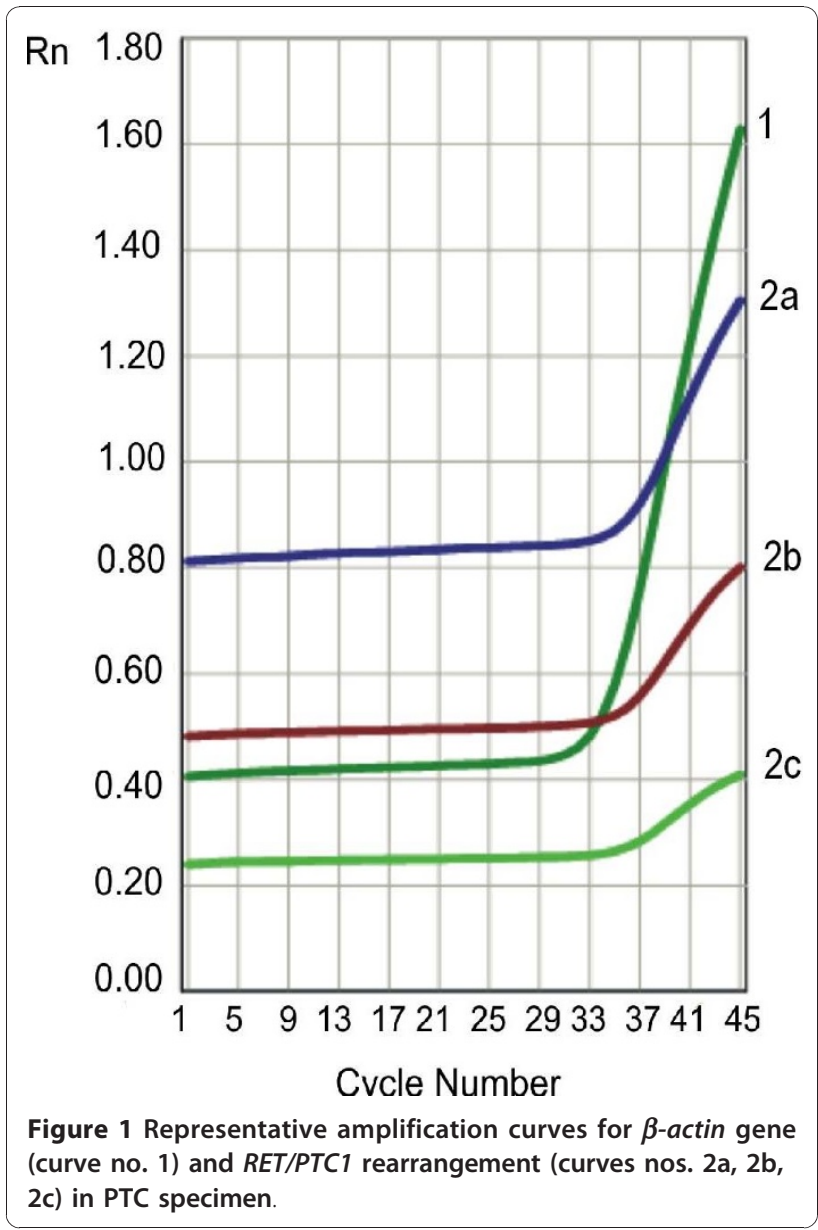

microcarcinoma. However, both of these studies had technical limitations, the authors used highly degraded RNA which was isolated from formalin-fixed and paraffin-embedded tissues. Kang et al. [16] have investigated the expression of RET, RAS and ERK proteins in oxyphilic cells in HT. They have shown greatly enhanced immunoexpression of these proteins, suggesting a molecular link between oxyphilic cell metaplasia in HT and the progression of PTC [16].

Rhoden et al. [11] have analyzed RET/PTC oncogenic activation in HT, PTC, oncocytic tumours and in normal thyroid samples using three independent techniques: real-time RT-PCR, laser capture microdissection (LCM) RT-PCR, and fluorescence in situ hybridization (FISH) method. In their study, normal samples have not shown $R E T$ protooncogene rearrangement. Sixty eight percent of HT were positive by FISH analysis, whereas only $17 \%$ HT have shown RET/PTC activation by realtime PCR. It is interesting that these conflicting results depended only on the method used in the study [11]. Despite some technical controversies (RT-PCR should be typically more sensitive method of detection than

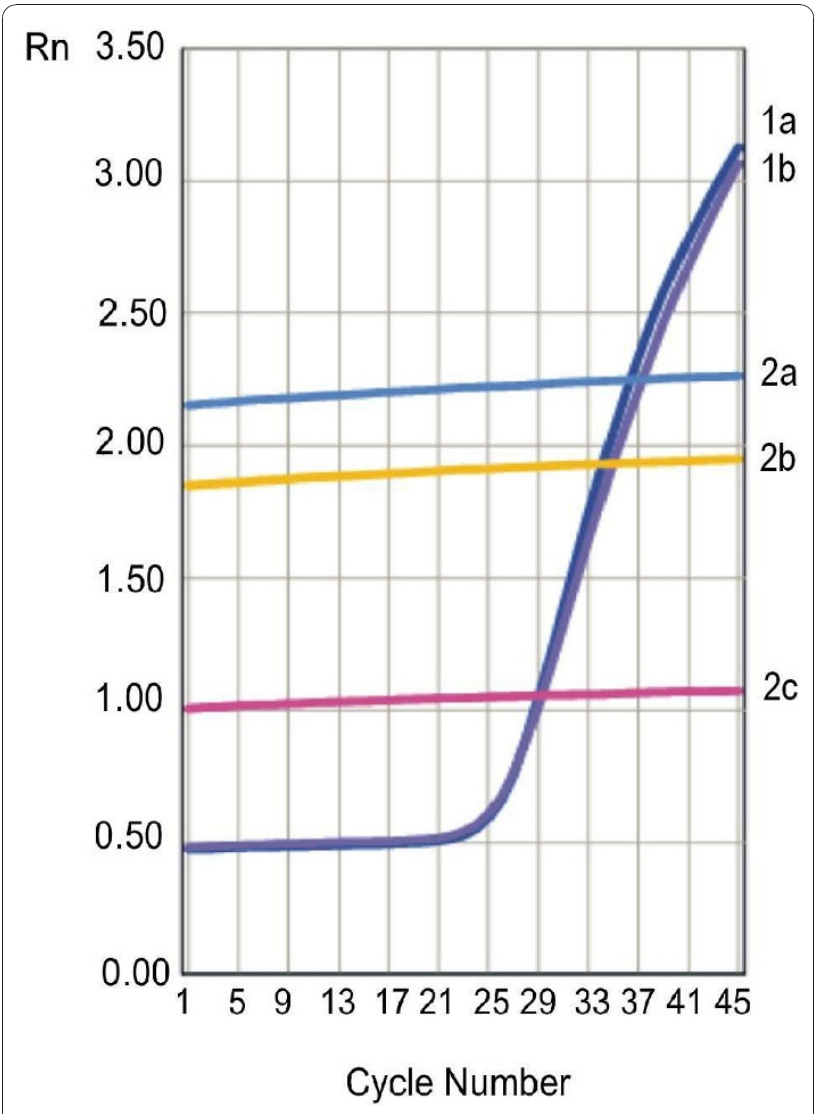

Figure 2 Representative amplification curves for $\beta$-actin gene (curves nos. 1a, 1b) and RET/PTC1 rearrangement (curves nos. $2 a, 2 b, 2 c)$ in HT specimen.

FISH), the importance of this paper is expressed through providing additional evidence for the possibility of presence RET/PTC rearrangements in a subpopulation of cells within the thyroid gland affected by HT.

On the other hand, other groups have not detected $R E T$ rearrangements in histologically benign thyroid tissue with HT. Moreover, they have not shown RET/PTC activation in PTCs arising on the background of HT, in contrast to PTC not associated with that disease [17]. Also, Sadow et al. have not identified RET/PTC1 and RET/PTC3 in dominant nodules from Hashimoto's goitre, supporting the notion that these nodules are neither malignant nor precursor lesions of PTC [18].

In our study, we have performed real-time relative PCR assay for RET/PTC1 and RET/PTC3 rearrangements, based on fluorescent TaqMan methodology and using the ABI PRISM 7500 Sequence Detection System (Applied Biosystems). Real-time PCR is a sensitive, precise technique for detection of nucleic acids. Unfortunately, we have not found RET/PTC1 and RET/PTC3 rearrangements in the examined samples of patients with HT. On one hand, it could be a result of the limited number of cases of HT in our study, on the other, 
it could suggest that the association between Hashimoto's thyroiditis and follicular cell-derived thyroid tumours, as well as RET/PTC rearrangements as a putative link between them, remain still controversial.

In summary, the results of our study indicate that RET/PTC1 and RET/PTC3 rearrangements in Hashimoto's thyroiditis, if any, are rather rare events and further investigations seem to be necessary to determine molecular changes associating Hashimoto's thyroiditis with PTC.

\section{Acknowledgements}

This study was supported financially by funds from the Medical University of Lodz, Poland (project no. 502-11-569).

\section{Author details}

'Department of Endocrinology and Metabolic Diseases, Medical University of Lodz, Poland. Polish Mother's Memorial Hospital - Research Institute, Lodz, Poland.

\section{Authors' contributions}

AC-M designed and coordinated the study, carried out the molecular genetic studies and drafted the manuscript. KW-D and KR-K participated in performing molecular studies. AZ participated in coordination of the study. $\mathrm{AL}$, the senior author, wrote the manuscript. All authors have read and approved the final manuscript.

\section{Competing interests}

The authors declare that they have no competing interests.

Received: 20 December 2010 Accepted: 10 January 2011 Published: 10 January 2011

\section{References}

1. Grieco M, Santoro M, Berlingieri MT, Melillo RM, Donghi R, Bongarzone I, Pierotti MA, Della Porta G, Fusco A, Vecchio G: PTC is a novel rearranged form of the ret proto-oncogene and is frequently detected in vivo in human thyroid papillary carcinomas. Cell 1990, 60:557-563.

2. Tallini G, Asa SL: RET oncogene activation in papillary thyroid carcinoma. Adv Anat Pathol 2001, 8:345-354.

3. Nikiforov YE: RET/PTC rearrangement in thyroid tumors. Endocr Pathol 2002, 13:3-16.

4. Santoro M, Dathan NA, Berlingieri MT, Bongarzone I, Paulin C, Grieco M, Pierotti MA, Vecchio G, Fusco A: Molecular characterization of RET/PTC3; a novel rearranged version of the RET proto-oncogene in a human thyroid papillary carcinoma. Oncogene 1994, 9:509-516.

5. Fusco A, Santoro M: 20 years of RET/PTC in thyroid cancer: clinicopathological correlations. Ara Bras Endocrinol Metabol 2007, 51:731-735.

6. Zhu Z, Ciampi R, Nikiforova MN, Gandhi M, Nikiforov YE: Prevalence of RET/ PTC rearrangements in thyroid papillary carcinomas: effects of the detection methods and genetic heterogeneity. J Clin Endocrinol Metab 2006, 91:3603-3610.

7. Bounancer A, Wicker R, Caillou B, Cailleux AF, Sarasin A, Schlumberger M, Suarez HG: High prevalence of activating RET proto-oncogene rearrangements in thyroid tumors from patients who had received external radiation. Oncogene 1997, 15:1263-1273.

8. Smida J, Salassidis K, Hieber L, Zitzelsberger $\mathrm{H}$, Kellerer AM, Demidchik EP, Negele T, Spelsberg F, Lengfelder E, Werner M, Bauchinger M: Distinct frequency of ret rearrangements in papillary thyroid carcinomas of children and adults from Belarus. Int J Cancer 1999, 80:32-38.

9. Tallini G, Santoro M, Helie M, Carlomagno F, Salvatore G, Chiappetta G, Carcangiu ML, Fusco A: RET/PTC oncogene activation defines a subset of papillary thyroid carcinomas lacking evidence of progression to poorly differentiated or undifferentiated tumor phenotypes. Clin Cancer Res 1998, 4:287-294.
10. Chiappetta G, Toti P, Cetta F, Giuliano A, Pentimalli F, Amendola I, Lazzi S, Monaco M, Mazzuchelli L, Tosi P, Santoro M, Fusco A: The RET/PTC oncogene is frequently activated in oncocytic thyroid tumors (Hürthle cell adenomas and carcinomas), but not in oncocytic hyperplastic lesions. J Clin Endocrinol Metab 2002, 87:364-369.

11. Rhoden KJ, Unger K, Salvatore G, Yilmaz Y, Vovk V, Chiappetta G, Qumsiyeh MB, Rothstein JL, Fusco A, Santoro M, Zitzelsberger H, Tallini G: RET/papillary thyroid cancer rearrangement in nonneoplastic thyrocytes: follicular cells of Hashimoto's thyroiditis share low-level recombination events with a subset of papillary carcinoma. J Clin Endocrinol Metab 2006, 91:2414-2423.

12. Rhoden KJ, Johnson C, Brandao G, Howe JG, Smith BR, Tallini G: Real-time quantitative RT-PCR identifies distinct c-RET, RET/PTC1 and RET/PTC3 expression patterns in papillary thyroid carcinoma. Lab Invest 2004, 84:1557-1570.

13. Brzeziańska E, Karbownik M, Migdalska-Sęk M, Pastuszak-Lewandoska D, Włoch J, Lewiński A: Molecular analysis of the RET and NTRK1 gene rearrangements in papillary thyroid carcinoma in the Polish population. Mutat Res 2006, 599:26-35.

14. Sheils OM, O'Leary JJ, Uhlmann V, Lüttich $\mathrm{K}$, Sweeney EC: ret/PTC-1 activation in Hashimoto thyroiditis. J Surg Pathol 2000, 8:185-189.

15. Wirtschafter A, Schmidt R, Rosen D, Kundu N, Santoro M, Fusco A, Multhaupt H, Atkins J, Rosen MR, Keane W, Rothstein JL: Expression of the RET/PTC fusion gene as a marker for papillary carcinoma in Hashimoto's thyroiditis. Laryngoscope 1997, 107:95-100.

16. Kang DY, Kim KH, Kim JM, Kim SH, Kim JY, Baik HW, Kim YS: High prevalence of RET, RAS, and ERK expression in Hashimoto's thyroiditis and in papillary thyroid carcinoma in the Korean population. Thyroid 2007, 11:1-7.

17. Nikiforova MN, Caudill CM, Biddinger P, Nikiforov YE: Prevalence of RET/PTC rearrangements in Hashimoto's thyroiditis and papillary thyroid carcinomas. Int I Surg Pathol 2002, 10:15-22.

18. Sadow PM, Heinrich MC, Corless CL, Fletcher JA, Nosé V: Absence of BRAF, NRAS, KRAS, HRAS mutations, and RET/PTC gene rearrangements distinguishes dominant nodules in Hashimoto thyroiditis from papillary thyroid carcinomas. Endocr Pathol 2010, 21:73-79.

doi:10.1186/1756-6614-4-5

Cite this article as: Cyniak-Magierska et al: Assessment of RET/PTC1 and RET/PTC3 rearrangements in fine-needle aspiration biopsy specimens collected from patients with Hashimoto's thyroiditis. Thyroid Research 2011 4:5.

\section{Submit your next manuscript to BioMed Central and take full advantage of:}

- Convenient online submission

- Thorough peer review

- No space constraints or color figure charges

- Immediate publication on acceptance

- Inclusion in PubMed, CAS, Scopus and Google Scholar

- Research which is freely available for redistribution 